\title{
6360 Sayılı Kanunun Kamu Hizmetlerinin Sunumuna Etkisi: Denizli Büyükşehir Belediyesi Örneği ${ }^{*}$
}

\author{
Mehmet Ali ÇAMDERE \\ Adnan Menderes Üniversitesi Sosyal Bilimler Enstitüsü, Tezli Yüksek Lisans \\ Öğrencisi, mehmetalicamdere@gmail.com \\ F. Neval GENÇ \\ Sorumlu Yazar: Adnan Menderes Üniversitesi Nazilli İ̈BF Siyaset Bilimi ve Kamu \\ Yönetimi Bölümü, fatmanevalgenc@gmail.com \\ $\ddot{O} \mathbf{z}$ \\ 6360 sayılı On Dört İlde Büyükşehir Belediyesi ve Yirmi Yedi İlçe Kurulması İle Bazı Kanun ve \\ Kanun Hükmünde Kararnamelerde Değişiklik Yapılmasına Dair Kanun ile kamu yönetimi \\ sisteminde önemli değişiklikler yapılmış̧ır. Çalışmada 6360 sayılı kanun öncesi ve sonrasındaki \\ idari örgütlenme şekilleri hakkında karşılaştırmalı değerlendirmeler yapılmıştır. Çalışmada 6360 \\ sayılı kanunun Denizli İlindeki kamu hizmeti üzerindeki etkileri değerlendirilmiștir. Çalışmada \\ Denizli İlinde bulunan 20 belediye yöneticisine 9 demografik, 45 araştırma sorusu olmak üzere 54 \\ sorudan oluşan anket çalışması yapılarak 6360 sayılı kanunun kamu hizmetleri sunumuna olan \\ etkileri belirlenmiştir.
}

Anahtar Kelimeler: Denizli Büyükşehir Belediyesi, Yerel Yönetim, Merkezi Yönetim, 6360.

Jel Sinıflandırma Kodları: H75, H83.

Impact of Law No. 6360 of Public Service Provision: The Case of Metropolitan Municipality Denizli $^{\dagger}$

\begin{abstract}
With the Law No. 6360 on the Establishment of the Fourteen Metropolitan Municipalities and Twenty-seven Districts and the Amendment of Certain Laws and Decrees on the Decree Law, significant changes were made in the public administration system. In the study, comparative evaluations were made about the forms of administrative organization before and after Law 6360 . In the study, the effects on the public service of Denizli Province of 6360 numbered law were evaluated. In the study, to 20 mayor a questionnaire consisting of 54 questions, 9 demographic and 45 research questions were conducted to determine the effects of the Law 6360 on public service provision.
\end{abstract}

Keywords: Denizli Metropolitan Municipality, Local Government, Central Government, 6360.

Jell Classification Codes: H75, H83.

\footnotetext{
* Bu makale aynı adlı yüksek lisans tezinden üretilmiştir.

${ }^{\dagger}$ Extended abstract is presented at the end of the article.
}

Attfta bulunmak için/Cite this paper:

Çamdere, M. A. ve Genç, F. N. (2018). 6360 Sayılı Kanunun kamu hizmetlerinin sunumuna etkisi: Denizli Büyükşehir Belediyesi örneği. Çankırı Karatekin Üniversitesi İIBF Dergisi. 8 (2), 35-60. 


\section{Giriş}

Kentleşme oranının hızlı biçimde artması, artan nüfusa hizmet sunumunun güçleşmesi, merkezi yönetim tarafından kamu hizmetlerinin planlanması ve uygulanması aşamasında sorunlar yaşanması, değişen ve gelişen dünyada kaliteli hizmet beklentilerinin artması hızlı büyüyen şehirleri diğerlerinden ayrı değerlendirme ihtiyacını doğurmuştur. Türkiye'de kentleşme hareketi 1950'li yıllarda hız kazanmıştır. Kentlere doğru hızlı göç hareketleri kontrolsüz bir hale gelerek kentleri dağınık ve plansız bir yapılanmaya sürüklemiş, idari ve siyasi parçalanmışlık, kırsal karakterli, hizmet üretme ve katılım imkanı sunma kapasitesi düşük, mali yapısı zayıf, cari harcamaları yüksek, verimliliği düşük belediye yapılarının ortaya çıkmasına neden olmuş, dağınık kent yapısı kamu hizmeti sunumunu olumsuz etkilemiştir. $\mathrm{Bu}$ durum yerel yönetimler yapılanmasında değişiklikler yapılmasını kaçınılmaz hale getirmiştir (Genç, 2014, s. 2).

1982 Anayasasında yer alan "Kanunla, büyük yerleşim merkezleri için özel yönetim biçimleri getirebilir" (m.127/3) maddesi Türkiye'de büyükşehir belediyelerinin kurulmasının zemini hazırlayan anayasal hükümdür. 1984 yılında 195 sayılı Büyükşehir Belediyelerinin Yönetimi Hakkında Kanun Hükmünde Kararname ile başlayan büyükşehir düzenlemesi aynı yıl çıkarılan 3030 sayılı Büyükşehir Belediyelerinin Yönetimi Hakkında Kanun Hükmünde Kararnamenin Değiştirilerek Kabulü Hakkında Kanunla şekillenmeye başlamıştır. 25 Mart 1984 tarihinde yapılan yerel seçimler sonrasında Ankara, İstanbul ve İzmir'de büyükşehir uygulamasına geçilmiş; yıllar içinde büyükşehir sayısı 16'ya ulaşmıştır.

2004 yılında büyükşehir belediye yönetimlerinin hukukî statülerinin düzenlenmesi ve buralardaki hizmetlerin plânlı, programl, etkin, verimli ve uyum içinde yürütülmesi amacıyla 5216 sayılı Büyükşehir Belediyesi Kanunu çıkarılmış, bu kanunla aynı zamanda İstanbul ve Kocaeli illerinde büyükşehir belediye sınırları il sınırı olarak kabul edilmiştir. 5216 sayılı Büyükşehir Belediyesi Kanunu ile büyükşehirlerin mekânsal kapsamı genişletilmiş, belde belediyeleri de sınır içine dahil edilmiş; büyükşehir belediyesine yakın ilçe belediyeleri büyükşehir ilçe belediyesi hâline dönüştürülmüş, büyükşehir olmada nüfus ölçütü 750.000'e çıkarılmıştır (Genç, 2014). Bu şekilde büyükşehir belediyelerinin kurulması ve sınırlarının belirlenmesine ilişkin yeni standartlar getirilmiştir; "pergel yasası" olarak anılan düzenlemeyle il mülki sınırları içinde valilik binası merkez kabul edilerek nüfusu 1 milyona kadar olan büyükşehirlerde yarıçapı $20 \mathrm{~km}, 1-2$ milyona kadar olanlarda $30 \mathrm{~km}, 2$ milyondan fazla olanlarda $50 \mathrm{~km}$ olan dairenin sınırı büyükşehir belediye sınırını oluşturmuştur.

2005 tarihli 5393 sayılı Belediye Kanunuyla belediyelere birleşme ve katma imkânı verilerek (11. madde uygulaması) küçük belediyeleşme ve optimal ölçek sorunları aşılmaya çalışılmıştır. Koşulları uygun olduğu takdirde çevrenin 
merkeze katılması olarak adlandırılabilecek bu düzenleme orta ölçekli kentsel alanların sorunlarına çözüm getirebilecekken özellikle kıyı bölgelerinde bir ilçeden diğer ilçeye uzanan yapı adalarında sorunu çözmekte beklenen başarıyı gösterememiş, 11. maddeyi uygulayan belediyelerin sayısı sınırlı kalmıştır (Arıkboğa, 2008, s. 28).

2008'de 5747 sayılı Büyükşehir Belediye Sınırları İçerisinde İlçe Kurulması ve Bazı Kanunlarda Değişiklik Yapılması Hakkında Kanunla o dönem mevcut sekiz büyükşehirde ilçe örgütü kurularak ilk kademe belediyeleri ilçe belediyelerine dönüştürülmüş, yeni ilçeler kurulmuştur (Genç, 2014). Kanunla 16 büyükşehir belediyesi içindeki 240 belde belediyesi mahalleye dönüştürülmüş, 43 yeni ilçe kurulmuş, 2000 nüfusun altından kalan 862 belde belediyesi köye dönüştürülmüş̧ür. Ancak köye dönüştürülme uygulamasında Anayasa Mahkemesi kararı ile kapatılmaktan kurtulmaya dönük bazı istisnalar getirilmiş, süresi içinde iptal davası açan 836 belediye köye dönüştürülmemiş ve belediye olarak seçimlere girebilmiştir (Zengin, 2014, s. 99). Bu kanunlarla büyükşehirlerin yönetim sorunları kısmen hafifletilebilmiş, ancak Antakya (Adıgüzel, 2014, s. 55), Aydın (Genç, 2014, Genç ve Özgür, 2009), Denizli, Kahramanmaraş, Kırıkkale, Malatya, Manisa, Ordu, Şanlıurfa, Trabzon, Zonguldak, Van gibi kentlerde idari ve siyasi parçalanmışlık sorunu devam etmiştir (Özgür, 2005, s. 475; Özgür, 2007, s.110).

61. Hükümet Programında, büyükşehirler konusunda radikal değişiklikler yapılacağı ve büyükşehir kurmada 750 bin nüfus koşulunun getirileceği, bazı belediyelerin büyükşehir belediyesine dönüştürüleceğine dair söylemler 2011 genel seçimleri öncesinde de sıklıkla ifade edilmiş ve nihayetinde 6360 sayılı kanun çıkarılmıştır.

On Dört İlde Büyükşehir Belediyesi ve Yirmi Yedi İlçe Kurulması ile Bazı Kanun ve Kanun Hükmünde Kararnamelerde Değişiklik Yapılmasına Dair Kanun 06/12/2012 tarih ve 28489 sayılı Resmi Gazetede yayımlanarak yürürlüğe girmiştir. Kanun tasarısının gerekçesinde ${ }^{3}$ özetle yeni düzenleme ile yerel yönetimlerin etkin hizmet üretmesi, bütüncül büyükşehrin tamamını kapsayan, makro ölçekte planlama ve koordinasyonun yapılması, optimal ölçekten faydalanılması, kaynak tasarrufu ve yönetsel sorunların üstesinden gelme gibi faydaların beklendiğinden söz edilmektedir. İl sınırında hizmet verecek büyükşehir belediye modeliyle geniş ölçekte hizmet üreten yerel yönetim birimlerinin gelişmiş teknolojilerle donatılabileceği, nitelikli teknik personel istihdam edilebileceği, iş gücünün uzmanlaşmasıyla verimlilik artışı, kaynakların etkin kullanımının sağlanacağı, yerel yönetim birimleri arasında kaynakların kullanımı ve sahip olunacak imkânlar açısından daha adil bir yapı ortaya çıkacağı, düzenleyici üst imar planları çerçevesinde il çapında uyumlu imar uygulamaları

\footnotetext{
${ }^{3}$ http://www2.tbmm.gov.tr/d24/1/1-0690.pdf (10.9.2018)
} 
gerçekleştirilebileceğine vurgu yapılmaktadır (Genç, 2016a, s. 275-276; Genç, 2016b).

Toplam 37 maddeden oluşan kanunun, 2 geçici maddesi bulunmakta ve bu kanunla birçok kanunda da değişiklikler yapılmaktadır. 6360 sayılı kanunda değişiklik yapan 6447 sayılı Kanun ile Ordu İli de büyükşehir statüsüne alınmış ve yeni büyükşehir sayısı 14'e çıkarılarak toplamda 30 büyükşehir belediyesi kurulmuştur. Bu Kanuna göre; Aydın, Balıkesir, Denizli, Hatay, Malatya, Manisa, Kahramanmaraş, Mardin, Muğla, Tekirdağ, Trabzon, Şanlıurfa, Van ve Ordu sınırları il mülki sınırı olmaktadır (RG. 22.03.2013, No: 28595). Büyükşehir belediye sınırı il mülki sınırı olmuş; büyükşehir olan illerde il özel idareleri kaldırılmış, 27 yeni ilçe kurulmuş, ilçe belediyelerinin sınırları ilçe mülki sınırı olmuş, belde belediyeleri ve köyler kaldırılmış ve mahalleye dönüştürülmüşlerdir. Büyükşehir olmayan illerde nüfusu 2.000 'den az olan belde belediyeleri köye dönüştürülmüştür (Bunların sayısı 559 idi, ancak 33 tanesi, kanun yürürlüğe girene kadar birleşme yoluyla nüfusunu arttırmayı başard,, 526's1 ise köye dönüştürüldü). 30 ilde valilikler bünyesinde Yatırım İzleme ve Koordinasyon Başkanlığı kurulmuştur; merkezi yönetim payları yeniden düzenlenmiş, maliye pay1 ise $\% 5$ 'ten $\% 6$ 'ya çıkarılmıştır. Bu değişikliklerle birlikte, Türkiye nüfusunun \%76's1, coğrafi alanın ise \%50'si büyükşehir sınırlarına dâhil olmuş; büyükşehir olan iller ve büyükşehir olmayan iller şeklinde ikili bir durum ortaya çıkmıştır. 6360 Sayılı Kanun öncesinde 5779 sayılı kanun çerçevesinde büyükşehir belediyeleri Genel Bütçe Vergi Gelirlerinden $\% 5$ pay (\%70 doğrudan, $\% 30$ nüfusa göre) alıyorken, 6360 Sayılı Kanun sonrasında bu pay \%6'ya (\%60 doğrudan, $\% 40$ havuzda toplanarak \%30'u yüzölçümüne,\%70'i nüfuslarına göre) çıkarılmıştır. Büyükşehir belediyelerine bağlı ilçe belediyelerine $\% 2,50$ pay (\%100 nüfusa göre, $\% 30$ 'u ilgili büyükşehir belediyesine, $\% 10$ 'u su kanalizasyon idaresine, \%60'1 büyükşehir ilçe belediyesine) verilirken, 6360 sayılı kanun sonrasında \%4,50 pay (\%10'u yüzölçümüne, \%90'^ nüfusa göre \%30'u ilgili büyükşehir belediyesine, $\% 10$ 'u su kanalizasyon idaresine, $\% 60$ 'ı büyükşehir ilçe belediyesine) verilmeye başlamıştır.

Bu makalede Denizli'de 6360 sayılı kanununla ortaya çıkan idari ve mülki değişikliklerin kamu hizmet alanları/ölçeğindeki değişikliklerin yerel yöneticiler tarafından nasıl değerlendirildiğini; süreçte yaşanan sorunları ve çözüm önerilerini ortaya koymak amaçlanmaktadır. "6360 sayılı kanunla getirilen yeni düzenlemelerin Denizli'de büyükşehir ve ilçe belediye başkanları tarafından nasıl algılandığı" çalışmanın ana problematiğini oluşturmaktadır. Bu amaçla makalede literatür taramasının ardından Denizli Büyükşehir Belediyesi ve 19 ilçe belediye başkanlığında yapılan anket çalışması yorumlanarak aktarılmaktadır. Amaçı ı örnekleme çeşitlerinden ölçüt örnekleme yönteminin kullanıldığı çalışmada 54 sorudan oluşan, 3 seçenekli Likert tipi anket formu hazırlanmış ve 20 belediye başkanına yüz yüze görüşme yöntemiyle uygulanmıştır. 


\section{Literatür Araştırması}

6360 sayılı kanunun kabul ve uygulanmaya başlamasından itibaren konu hakkında akademik çalışmalar da yapılmaya başlamıştır.

\section{1. Önceki Çalışmalar}

6360 sayılı kanunla alakalı çalışmalar son dönemde daha fazla ilgi çekmeye başlamıştır. Makale konusuyla bağlantılı olarak yapılmış olan öncü çalışmalara örnek olarak Çınar, Çiner ve Zengin (2009) "Büyükşehir Yönetimi Bütünleștirme Süreci” adlı kitapları, Karaaslan (2012) "Nasıl Bir Yerel Yönetim? 6360 Sayılı Kanun Üzerine Bir Değerlendirme", İzci ve Turan (2013), “Türkiye'de Büyükşehir Belediyesi Sistemi ve 6360 Sayılı Yasa İle Büyükşehir Belediyesi Sisteminde Meydana Gelen Değişimler: Van Örneği”, Ürkmez ve Çelik (2016), "6360 Sayılı Yasayla Mekânsal İlişki Sisteminin Kır- Kent İkileminde Yeniden Yapılanış1 ve Yerel Yönetimler: Kayseri İli Örneği”, Genç (2014) “6360 Sayılı Yasa ve Aydın'a Etkileri”; Demirkaya ve Koç (2017) “6360 Sayılı Kanun İle Birlikte Mahalleye Dönüşen Köylerde Değişimin Katılım Açısından Muhtarlığa Etkisi: Menteşe ve Seydikemer İlçeleri Üzerinden Bir Değerlendirme"; Göküş ve Alptürker (2016) "6360 Sayılı Yasa İle Köy Yönetiminden Mahalle Yönetimine Geçiş Sonrası Etkin Hizmet Sunumuna İlişkin Muhtarların Görüşü: Silifke Köyleri Örneğì” adlı çalışmalar verilebilir. Son dönemde bunlara yeni çalışmalar da eklenmiştir. Konuyla alakalı olarak az da olsa uygulamaya, alana dayalı çalışmalar da yapılmıştır; Genç ve Daşcı (2016), "6360 sayılı Yasanın Kamu Hizmetlerinin Sunumuna Etkisi: Balıkesir Büyükşehir Belediyesi Örneği” isimli makalede 6360 sayılı kanunun kamu hizmeti üzerine etkilerini değerlendirmiş, kanunun meydana getirdiği değişiklikleri ortaya koymuştur. Genç ve Korkın (2017) "6360 Sayılı Kanunla Tüzel Kişiliği Kaldırılan Belde Belediyelerinde Halkın Uygulamaya İlişkin Algısı: Atça (Sultanhisar-Aydın) Örneği” de bir başka örnektir.

Denizli'de kentleşme, alan yönetimi konularında kentin büyükşehir statüsü elde etmesine kadar olan dönemde yapılan çalışmalar da mevcuttur. Özgür (2014), “Denizli Kenti ve İlinde Yönetsel Ölçek Arayışları (1976-2014): Dört Bütünşehir Belediyesi Söylemi / Tasavvuru (2001-2014) ve Büyükşehir Belediyesi Statüsü (2012-2014)" isimli makalesinde Denizli’nin belediyeleşme süreci ve büyükşehir olma mücadelesi hakkında, kentsel alan yönetimi konusunda bilgi vermektedir. Özgür (2008), "Yerel Siyaset Perspektifinden Bakışla Büyükşehir Belediyelerinde Kentsel Alan Yönetimi Uygulamaları" isimli makalesinde Türkiye'deki büyükşehir hareketlerinden bahsetmiş, çıkarılan kanunların amaçlarını ve etkilerini irdelemiştir. Özgür ve Savaş Yavuzçehre (2016), “Türkiye'nin Büyükşehir Belediyesi Sistemi: 1982-2015" isimli makalelerinde ilk büyükşehir uygulamaları ve 6360 sayılı kanuna kadar olan büyükşehir belediye sistemine ait kanunları, kanun hükmünde kararnameleri, düzenlemeleri, kanun tekliflerini incelemekte, sıklıkla değișen ve tek kanuna dayalı büyükşehir belediye sisteminin 
eksikliklerini ortaya koymaktadır. Özgür vd. (2007), “Türkiye’de Büyükşehir Belediyesi Kurma ve Kentsel Alan Yönetimi Siyaseti ve Siyasaları" isimli makalelerinde büyükşehir olma kriterlerini, büyükşehir belediyesi kurma kurallarını, büyükşehir yönetme siyasetini incelemişler, metropolitenleşen kentlerdeki yönetimsel sorunları ortaya koymuşlardır. Savaş Yavuzçehre (2010), "Kentsel Mekân Kullanımında Değişim: Denizli Kenti Örneğii" isimli doktora tezinde, Denizli'nin tarihsel gelişim süreci, metropol yapısına ulaşma süreci ve bütünşehir deneyimleri hakkında bilgi vermektedir.

Bu makalenin farklı olan tarafi ise 6360 sayılı kanuna odaklanmış olması, sadece Denizli üzerinde yapılmış olması ve alan araştırmasına dayanmasıdır.

\subsection{Denizli’de Büyükşehirleşme Süreci}

Tarihin hemen her aşamasında yerleşimin olduğu Denizli ${ }^{4}$ sahip olduğu doğal, tarihi miras ve geleneksel dokumacılık faaliyeti, takip eden dönemde modern tekstil sanayinin gelişimi, turizm ve mermercilik faaliyetleriyle Türkiye'nin gelişmiş kentlerinden biridir. Denizli İlinin nüfusu 2016 y1lı TÜİK verilerine göre 1.005.687 kişidir. Bu nüfusu ile Türkiye'nin en kalabalık 21. şehri konumundadır. Denizli İli gerek coğrafi konumu itibariyle gerekse sosyo-ekonomik yapısı itibariyle yaşam, iş ve ulaşım kolaylıklarını birlikte sunmaktadır. Bu nedenle göçlerle il nüfusu sürekli artış eğilimindedir.

Denizli Belediyesi 1876 yılında kurulmuştur. İlk belediye başkanı Hacı Molla Ahmet Efendi'dir. Cumhuriyet dönemine kadar Hacı Tevfik Bey belediye başkanı olarak görev yapmıştır. Denizli 1883 yılına kadar Aydın'a bağlı bir ilçe iken 1910 yılında bağımsız mutasarrıflık; Cumhuriyet'in ilanı ile il haline gelmiştir (Savaş Yavuzçehre, 2010, s. 163-164). 6360 Sayılı Kanunla büyükşehir statüsünü alan Denizli, büyükşehir olma yoluna daha önceden girmiştir. Sanayisinin gelişimi ile Denizli 1990'lı yıllarda çevreden göç alarak metropoliten bir yapıya ulaşmıştır (Savaş Yavuzçehre, 2010, s. 153-154). 1970'li yılların ortalarına kadar savaştan çıkmış yorgun ve bitkin kent görüntüsünü ve 1976 yılındaki depremin izlerini silmeye çalışan Denizli halkı bu yıllarda sanayileşmeye yönelmiştir. 1953 yılında Sümerbank Fabrikası'nın ve fabrikanın elektrik ihtiyacını gidermek için 1954

\footnotetext{
${ }^{4}$ Denizli yöresinin ilk ve en önemli yerleşim yeri günümüzde Çivril İlçesine $5 \mathrm{~km}$ uzaklıkta yer alan Beycesultan Höyügü dür. Denizli yöresinin bilinen ilk sakinleri Arzavalılar olmuştur. M.Ö 1200-1700 arası süren Karanlık Çağ'dan sonra yöreye Frigler hakim olmuşlardır. Frigya'nın batı sınırlarındaki en önemli yerleşimlerinden biri Collosai (bugün Honaz) şehri idi. Friglerden sonra Lidyalılar ve Romalılar bölgede hüküm sürmüştür. Roma İmparatorluğu'nun bölünmesiyle Doğu Roma İmparatorluğu (Bizans İmparatorluğu) hakimiyetinde kalan şehir 1206-1207 yıllarında Türk hakimiyetine girmiştir. Sırasıyla Sahip Ataoğulları, Germiyanoğulları ve İnançoğulları Beylikleri yörede hâkimiyet kurmuşlardır. 1429 yılında Denizli Osmanlıların eline geçmiştir. Sosyal ve ekonomik yönden Denizli 14. ve 15. yüzyıllarda doruk noktasını yaşamış ve büyük bir ticaret merkezi haline gelmiştir (Denizli Valiliği, 2017).
} 
yılında Gökpınar Elektrik Santralinin yapılması ilk kentsel alan kullanımı olup sosyal hareketliliği hızlandırmaya başlamıştır (Savaş Yavuzçehre, 2010, s. 169).

Tablo 1: Denizli ve İlçelerine Dair Temel Veriler ${ }^{5}$

\begin{tabular}{|c|c|c|c|c|c|c|c|c|c|}
\hline $\begin{array}{l}\stackrel{0}{Z} \\
\stackrel{\pi}{=}\end{array}$ & $\begin{array}{l}\vec{Z} \\
0 \\
.0 \\
.\end{array}$ & 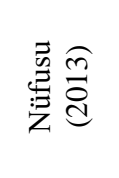 & 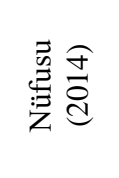 & 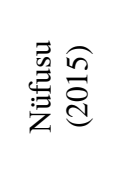 & 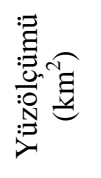 & 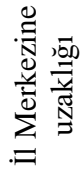 & 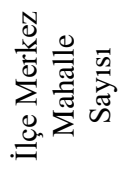 & 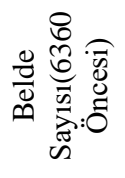 & 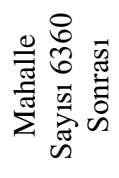 \\
\hline 1 & Pamukkale & 311.496 & 320.142 & 331.000 & 823 & 0 & Yeni İlçe & \multirow{2}{*}{18} & 68 \\
\hline 2 & Merkezefendi & 262.825 & 271.942 & 280.341 & 336 & 0 & Yeni İlçe & & 50 \\
\hline 3 & Acıpayam & 55.971 & 55.722 & 55.406 & 1772 & 55 & 5 & 11 & 56 \\
\hline 4 & Babadağ & 6.707 & 6.623 & 6.611 & 124 & 37 & 3 & 0 & 12 \\
\hline 5 & Baklan & 5.934 & 5.800 & 5.816 & 283 & 59 & 2 & 2 & 14 \\
\hline 6 & Bekilli & 7.751 & 7.512 & 7.164 & 304 & 82 & 3 & 1 & 15 \\
\hline 7 & Beyağaç & 7.116 & 6.922 & 6.713 & 333 & 106 & 7 & 0 & 14 \\
\hline 8 & Bozkurt & 12.279 & 12.352 & 12.597 & 462 & 49 & 6 & 1 & 20 \\
\hline 9 & Buldan & 27.558 & 27.455 & 27.359 & 523 & 47 & 16 & 1 & 45 \\
\hline 10 & Çal & 20.587 & 20.218 & 19.699 & 860 & 63 & 3 & 6 & 34 \\
\hline 11 & Çameli & 19.315 & 18.819 & 18.442 & 758 & 106 & 3 & 0 & 31 \\
\hline 12 & Çardak & 9.386 & 9.076 & 8.906 & 423 & 56 & 6 & 2 & 17 \\
\hline 13 & Çivril & 60.615 & 61.007 & 60.716 & 1570 & 93 & 10 & 6 & 76 \\
\hline 14 & Güney & 10.796 & 10.697 & 10.399 & 362 & 74 & 7 & 1 & 24 \\
\hline 15 & Honaz & 32.324 & 32.282 & 31.779 & 449 & 21 & 6 & 3 & 22 \\
\hline 16 & Kale & 21.293 & 21.133 & 20.667 & 684 & 68 & 5 & 2 & 32 \\
\hline 17 & Sarayköy & 29.650 & 29.739 & 29.964 & 379 & 23 & 7 & 4 & 32 \\
\hline 18 & Serinhisar & 14.817 & 14.796 & 14.649 & 256 & 36 & 7 & 1 & 11 \\
\hline 19 & Tavas & 47.044 & 46.463 & 45.214 & 1432 & 43 & 4 & 9 & 50 \\
\hline $\begin{array}{l}\mathrm{T} \\
\mathrm{O} \\
\mathrm{P} \\
\mathrm{L} \\
\mathrm{A} \\
\mathrm{M}\end{array}$ & -- & 963.464 & 978.700 & 993.442 & 12.133 & & 100 & 68 & 623 \\
\hline
\end{tabular}

1970’li yılların sonlarında kente yakın 34 köy, dönemin Belediye Başkanı Hasan Gönüllü tarafından merkeze dahil edilmek istense de bu teşebbüs sonuçsuz kalmış; bu köyler artan nüfusları ile birlikte belediye olmuşlardır. Buradaki temel amaç kentin gelişiminin kontrol altında tutulması ve etraftaki yerlerin kentin imar bütünlüğüne uyum sağlamasıdır. Belediye mücavir alanına alınan köyler gerek nüfus artışı ile gerekse kendi aralarında birleşerek belediye olma hakkı elde etmişlerdir. Bunların gerekçeleri ise belediyenin çalışmalarından memnun olmamaları hatta yeteri kadar hizmet alamamaları olmuştur. Türkiye'de o dönemde yaygın bir şekilde görülen belediyeleşme hareketi Denizli İlinde de

5 Tablo, YSK, KGM, Pamukkale Belediyesi, Merkezefendi Belediyesi, İçişleri Bakanlığı verileri kullanılarak yazarlar tarafindan oluşturulmuştur. 
görülmüş ve bu konuda siyasi telkinler ve çıkarlar, belediye başkanı olma istekleri vb. belediyeleşme hareketini hızlandırmıştır.

Denizli'de 1992 yılına kadar 9 olan belediye sayıs1 1999 yılında 22'ye yükselmiştir. 1993 yllından itibaren belediye meclisi gündemine taşınan parçalanmış idari yapı, bu süreçte Denizli'nin büyükşehir statüsüne alınması hususundaki kanun tekliflerinin birincil nedeni olmuştur. 1999-2004 döneminde başkanlık yapan Ali Aygören konunun önemini çeşitli oturumlarda dile getirmiş, Denizli'nin büyükşehir olmasından daha önemli olan konunun imar bütünlügüne sahip çıkılmaması olduğunu, Denizli Belediyesi'nin etrafında yer alan küçük belediyelerin ve köylerin mahalle olarak merkez belediyeye bağlı olmamalarının imar bütünlüğünü bozan temel faktör olduğunu savunmuştur. 1993 yılında 7 ile büyükşehir statüsünün verilmesi Denizli'nin büyükşehir olması fikrini güçlendirmiş ve 1970'li yıllardaki belediyeleşmenin yerini 1990'l y yllarda büyükşehir olma mücadelesi almıştır. 1998-2002 yıllarındaki büyükşehir belediyesi tasarılarındaki nüfus ölçütleri (300.000 veya 500.000) Denizli için bir umut olsa da hayata geçirilememiştir (Özgür, 2014, s. 34-36).

6360 sayılı kanundan önceki dönemde Denizli'de giderek genişleyen kentin yönetimine dair alternatifler, yeni ilçeler kurulması veya büyükşehir olma vb öneriler muhtelif zamanlarda dile getirilmiş ancak karşılık bulmamıştır. 1999 yılında Denizli milletvekili Beyhan Aslan kentin hizmet alanının genişlemesi, enerji su, enerji, kanalizasyon ve imar planlarının uyumsuzluk göstermesi gerekçeleri ve bunlardaki bütünlüğün sağlaması amacıyla Denizli'de büyükşehir belediyesi kurulması konusunda kanun teklifinde bulunmuştur. Ancak bu teklif reddedilmiştir. Büyükşehir olma konusunda gerçekçi adımların atılamaması üzerine Başkan Ali Aygören, Denizli İlinin etrafında yer alan belde belediye başkanları ile ortak kararlar almaya çalışmıştır. Bu konuda birkaç kez toplantı da yaparak bütünşehir konusunda ilk adımların atılmasını sağlamıştır. 2003 yılında 47 yerleşimi içerecek ve Akköy ilçe merkezini dışarıda bırakacak şekilde teklif sunulmuştur. Bu teklif TBMM'den geçerek 5026 Kanun numarasını almış, 'Bazı Belediye ve Köylerin Denizli Belediyesine Katılmasına İlişkin Kanun’ adıyla 10. Cumhurbaşkanı Ahmet Necdet Sezer'e sunulmuştur. Ancak Ahmet Necdet Sezer tarafından bu kanun, seçime 1 yıldan az süre kalması tali nedeniyle veto edilmiştir (Özgür, 2014, s. 36; Özgür, Savaş Yavuzçehre, Ciğeroğlu, 2007, s. 6). 5393 sayılı kanunla Denizli'de 13 belediye ve 10 köyde bu maddenin uygulanmasını kararlaştıran 2006/8352 sayılı sınır tespiti kararı (Üçlü Kararname) da Denizli'de halk, basın ve diğer ilgililer tarafından yine "bütünşehir" belediyesi olarak isimlendirilmiştir (Özgür, 2014, s. 37).

Denizli 6360 sayılı kanun öncesinde 1 merkez belediye, 18 ilçe belediyesi, 68 belde belediyesi olmak üzere toplam 87 belediye ve 359 köye sahipti. 6360 sayılı 
kanun sonrasında merkezde Pamukkale ${ }^{6}$ ve Merkezefendi ${ }^{7}$ ilçeleri kurulmuş, merkeze $23 \mathrm{~km}$ uzaklıkta ve 5392 nüfuslu Akköy ilçe belediyesi kapatılarak Merkezefendi İlçesine mahalle olarak bağlamıştır (6360 SK/11.Md, Ek 4); 2 merkez ilçe, 17 ilçe belediyesi ve 623 mahalle kurulmuştur. 6360 sayılı kanunun 2. maddesinin 4. bendi ekli 3 liste ile Denizli Belediyesi'ne bağlı olan mahalleler ve köylerden oluşan Merkezefendi İlçesi kurulmuştur. Bu şekilde Merkezefendi İlçesi 50 mahalleye sahip olmuştur (6360 SK/11.Md, Ek 3). 6360 sayılı kanunun 2. maddesinin 5. bendi ekli 4 liste ile Akköy İlçesi sınırlarındaki mahalleler, Denizli Belediyesi'ne bağlı olan köyler ve mahalleler ile Akköy İlçesi'nin adı değiştirilerek Pamukkale İlçesi kurulmuştur. Bu şekilde Pamukkale İlçesi 68 mahalleye sahip olmuştur.

\section{Tablo 2: 6360 Sayılı Kanun Öncesi ve Sonrası Denizli’de İdari Durum ${ }^{8}$}

\begin{tabular}{|l|r|r|r|r|}
\hline Yıllar & İlçe Sayısı & Belediye Sayısı & Köy Sayısı & Mahalle Sayısı \\
\hline 2011 & 18 & 87 & 359 & 284 \\
\hline 2014 & 19 & 20 & -- & 623 \\
\hline
\end{tabular}

6360 sayılı kanun sonrasında Denizli'de Pamukkale, Merkezefendi, Acıpayam, Babadağ, Baklan, Bekilli, Beyağaç, Bozkurt, Buldan, Çal, Çameli, Çardak, Çivril, Güney, Honaz, Kale, Sarayköy, Serinhisar ve Tavas olmak üzere 19 ilçe

\footnotetext{
${ }^{6} 6360$ sayılı kanun sonrasında Pamukkale İlçesi’ne bağlanan merkez mahalleler; Akhan, Aktepe, Anafartalar, Asmalıevler, Atalar, Bağbaşı, Cankurtaran, Cumhuriyet, Çamlaraltı, Deliktaş, Dokuzkavaklar, Fatih, Fesleğen, Goncalı, Gökpınar, Güzelköy, Hacıkaplanlar, Hürriyet, İncilipınar, İstiklal, Kale, Karakova, Karakurt, Karşıyaka, Kayıhan, Kervansaray, Korucuk, Kuşpınar, Mehmetçik, Onbeş Mayıs, Pelitlibă̆, Siteler, Tekke, Topraklık, Yunus Emre, Zeytinköy ve Zümrüt olmak üzere 37 tanedir. Pamukkale İlçesi'ne mahalle olarak bağlanan belde belediyeleri; Irlıganlı, Gözler, Karahayıt, Pamukkale, Pınarkent ve Uzunpınar Belediyesi, mahalle olarak bağlanan köyler ise; Akdere, Develi, Eldenizli, Eymir, Güzelpınar, Haytabey, Karataş, Kocadere, Kurtluca, Küçükdere ve Yeniköy olmak üzere 17 tanedir. Akköy İlçesi'ne bağlı olup kanun sonrasında Pamukkale İlçesi'ne bağlanan mahalle ve köyler ise; Adnan Menderes, Akçapınar, Atatürk, Aziziye, Belenardıç, Çerkez, Çeşmebaşı, Gölemezli, Kavakbaşı, Mahmut Sönmez, Oğuz, Sami Türel olmak üzere 12 tanedir. Merkeze bağlı Karataş Köyü ve Kınıklı Belediyesi de Pamukkale İlçesi’ne bağlanarak mahalle sayısı 68'e ulaşmıştır (6360 SK/11.Md, Ek 4).

${ }^{7} 6360$ sayılı kanun sonrasında Merkezefendi İlçesi’ne bağlanan mahalleler; 1200 Evler, Adalet, Akçeşme, Akkonak, Alpaslan, Altıntop, Bahçelievler, Barbaros, Barutçular, Bereketler, Bozburun, Çakmak, Değirmenönü, Servergazi, Eskihisar, Gerzele, Göveçlik, Gültepe, Gümüşçay, Hacieyüplü, Hallaçlar, Hisar, İlbade, Kadılar, Karahasanlı, Karaman, Kayalar, Mehmet Akif Ersoy, Merkezefendi, Muratdede, Saraylar, Saruhan, Selçuk Bey, Sevindik, Sırakapılar, Sümer, Şemikler, Şirinköy, Yeni, Yenişafak, Yenişehir ve Zafer olmak üzere 42 tanedir. Merkezefendi İlçesi'ne mahalle olarak bağlanan belde belediyeleri; Aşağışamlı, Başkarcı Belediyeleri, mahalle olarak bağlanan köyler ise; Altındere, Çeltikçi, Kumkısık, Salihağa, Üzerlik, Yeşilyayla olmak üzere toplamda 8 tanedir (6360 SK/11.Md, Ek 3).

${ }^{8}$ İçişleri Bakanlığı ve Mahalli İdare Birlikleri verilerinden yazarlar tarafından derlenmiştir.
} 
bulunmaktadır. En kalabalık ilçe Çivril'dir. Merkeze en uzak olan ilçeler $106 \mathrm{~km}$ ile Beyağaç ve Çameli'dir. Merkeze en yakın olan ilçe ise $21 \mathrm{~km}$ ile Honaz'dır.

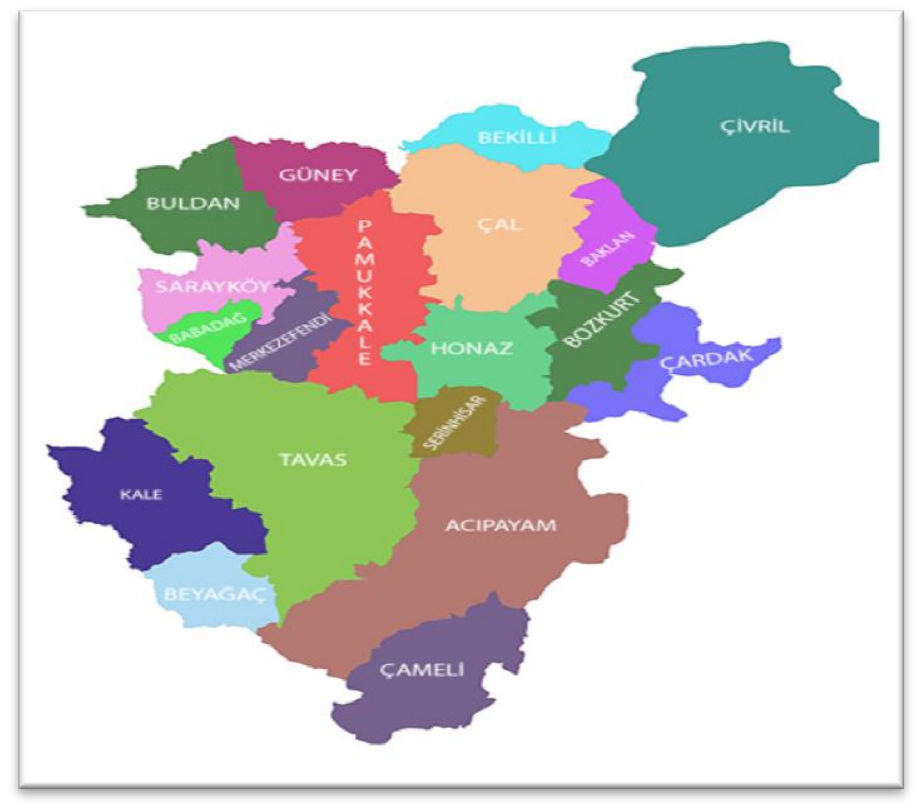

Şekil 1: Denizli İli ve İlçeleri Haritası

Kaynak: http://www.denizli.bel.tr/Default.aspx?k=content\&id=14225

Tablo 3: 6360 Sayılı Kanun Öncesi ve Sonrasına İlişkin Denizli’nin İlçelerinin Gelirlerine Dair Veriler

\begin{tabular}{|r|l|r|r|r|r|r|}
\hline Sıra No. & ilçe Adı & $\begin{array}{c}\text { Nüfusu } \\
(2013)\end{array}$ & $\begin{array}{c}\text { Yüzölçümü } \\
\text { (Km2) }\end{array}$ & $\begin{array}{c}\text { Öncesi } \\
\text { Geliri } \\
\text { (Bin TL) }\end{array}$ & $\begin{array}{c}6360 \\
\text { Sonrası } \\
\text { Geliri } \\
\text { (Bin TL) }\end{array}$ & $\begin{array}{c}\text { Artı̧ } \\
\text { Oranı } \\
(\%)\end{array}$ \\
\hline 1 & Pamukkale & 311.496 & 823 & Yeni IIlçe & 31.129 & - \\
\hline 2 & Merkezefendi & 262.825 & 336 & Yeni İlçe & 30.208 & - \\
\hline 3 & Acıpayam & 55.971 & 1772 & 4052 & 9.093 & 124 \\
\hline 4 & Babadağ & 6.707 & 124 & 954 & 1.598 & 67 \\
\hline 5 & Baklan & 5.934 & 283 & 679 & 1.756 & 159 \\
\hline 6 & Bekilli & 7.751 & 304 & 1.096 & 1.813 & 66 \\
\hline 7 & Beyağaç & 7.116 & 333 & 850 & 1.559 & 84 \\
\hline 8 & Bozkurt & 12.279 & 462 & 1.355 & 1.931 & 43 \\
\hline 9 & Buldan & 27.558 & 523 & 3.954 & 3.850 & -3 \\
\hline 10 & Çal & 20.587 & 860 & 1.264 & 3.929 & 211 \\
\hline 11 & Çameli & 19.315 & 758 & 1.088 & 3.396 & 212 \\
\hline 12 & Çardak & 9.386 & 423 & 1.278 & 2.142 & 68 \\
\hline 13 & Çivril & 60.615 & 1570 & 5.482 & 9.297 & 70 \\
\hline 14 & Güney & 10.796 & 362 & 2.058 & 2.156 & 5 \\
\hline 15 & Honaz & 32.324 & 449 & 2.347 & 4.332 & 85 \\
\hline 16 & Kale & 21.293 & 684 & 2.808 & 3.527 & 26 \\
\hline 17 & Sarayköy & 29.650 & 379 & 4.176 & 3.988 & -4 \\
\hline 18 & Serinhisar & 14.817 & 256 & 2.730 & 2.044 & -25 \\
\hline 19 & Tavas & 47.044 & 1432 & 3.828 & 8.147 & 113 \\
\hline TOPLAM & -- & 963.464 & 12.134 & -- & -- & -- \\
\hline
\end{tabular}

Kaynak: TEPAV, 2014 Erişim Tarihi: 07.11.2018 
Denizli'de ilçe belediyelerinin 6360 sayılı kanun öncesindeki ve sonrasındaki yıllık gelirleri kıyaslandığında 3 ilçenin (Buldan, Sarayköy, Serinhisar) gelirlerinin düştüğü görülmektedir. Özellikle Serinhisar İlçesinin gelirindeki \%25'lik düşüş yaklaş1k 700 bin TL kayba sebep olmaktadır. İlçelerin sosyoekonomik gelişmişlik sıralamasında Denizli ilçeleri içerisinde 5. sınıfta yer alan tek ilçe olan Çameli'nin gelir düzeyindeki \%212'lik artış ilçe belediyesinin bütçesine yaklaşık 2.300.000 TL/ Yıl ek katkı sağlamıştır.

Tablo 4: Denizli (Büyükşehir) Belediye Başkanlığı Yerel Seçim Sonuçları 9

\begin{tabular}{|l|r|r|r|}
\hline \multicolumn{1}{|c|}{ Parti Ad 1} & $2014(\%)$ & $2009(\%)$ & \multicolumn{2}{c|}{$2004(\%)$} \\
\hline AK Parti & 45,3 & 40 & 42,3 \\
\hline MHP & 11,9 & 21,9 & 6,1 \\
\hline CHP & 38,7 & 30,1 & 25,4 \\
\hline DYP & 0,2 & - & 19,8 \\
\hline ANAP & - & - & 1,4 \\
\hline SP & 0,5 & 0,8 & 0,6 \\
\hline BBP & 0,9 & 1,2 & 0,06 \\
\hline HDP & 1,1 & 0,2 & - \\
\hline DSP & - & - & 0,9 \\
\hline
\end{tabular}

2002 yılındaki genel seçimlerin etkisi 2004 yılından başlamak üzere 3 dönemdir Denizli'de devam etmektedir. 2004 ve 2009 yerel seçimlerinde merkez belediye başkanı AKP'den seçilmiştir.

2004 yerel seçimlerinde Denizli'de AKP'den 10, CHP'den 5, MHP'den 2 ve DYP'den 2 belediye başkanı seçilmiştir. 6360 sayılı kanundan sonra Pamukkale Belediyesi'ne mahalle olarak katılan Akköy'ün son belediye başkanı DSP'den seçilmiştir. 2014 yerel seçimlerinde 1'i büyükşehir belediyesi ve 2'si merkez ilçe olmak üzere AKP'den 16, CHP'den 3 ve MHP'den 1 belediye başkanı seçilmiştir. Denizli Büyükşehir Belediyesi Meclisi 50 AKP'li, 18 CHP'li ve 7 MHP'li olmak üzere toplam 75 üyeden oluşmaktadır (Denizli Büyükşsehir Belediyesi, 2017).

\footnotetext{
${ }^{9}$ YSK verilerinden yazarlar tarafindan derlenmiştir.
} 
Tablo 5: Denizli İli İlçe Belediye Başkanlıklarının Partilere Göre Dağılımı ${ }^{10}$

\begin{tabular}{|r|l|l|l|l|}
\hline Sıra No. & \multicolumn{1}{|c|}{ ilçe Adı } & 30.Mar.14 & 29.Mar.09 & 28.Mar.04 \\
\hline 1 & Pamukkale & AK Parti & - & - \\
\hline 2 & Merkezefendi & AK Parti & - & - \\
\hline 3 & Acıpayam & AK Parti & CHP & DYP \\
\hline 4 & Akköy & - & DSP & AK Parti \\
\hline 5 & Babadağ & AK Parti & MHP & AK Parti \\
\hline 6 & Baklan & AK Parti & MHP & DYP \\
\hline 7 & Bekilli & CHP & CHP & AK Parti \\
\hline 8 & Beyağaç & AK Parti & AK Parti & AK Parti \\
\hline 9 & Bozkurt & CHP & AK Parti & CHP \\
\hline 10 & Buldan & CHP & AK Parti & MHP \\
\hline 11 & Ģal & MHP & AK Parti & AK Parti \\
\hline 12 & Çameli & AK Parti & AK Parti & AK Parti \\
\hline 13 & Çardak & AK Parti & AK Parti & AK Parti \\
\hline 14 & Çivril & AK Parti & CHP & AK Parti \\
\hline 15 & Güney & AK Parti & CHP & CHP \\
\hline 16 & Honaz & AK Parti & AK Parti & CHP \\
\hline 17 & Kale & AK Parti & MHP & AK Parti \\
\hline 18 & Sarayköy & AK Parti & CHP & CHP \\
\hline 19 & Serinhisar & AK Parti & CHP & CHP \\
\hline 20 & Tavas & AK Parti & AK Parti & MHP \\
\hline & & & & \\
\hline & & & \\
\hline & &
\end{tabular}

\section{Araştırma Metodolojisi}

6360 sayılı kanunla belediye sorumluluk alanının il sınırlarının tamamını kapsamasının hizmet sunumuna olan etkilerinin değerlendirilmesi, yaşanılan güçlüklerin tespit edilmesi, hizmet sunumunda aksamalara yol açıp açmadığının analizi, genel anlamda kanunun gerekçesinde de belirtilen faydaların ortaya çıkıp çıkmadığının sorgulanması; Denizli üzerine yapılan bu alan araştırmanının amaçlarındandır.

6360 sayılı kanun ile büyükşehir belediyesi statüsüne kavuşan 14 il ile daha önceden büyükşsehir belediyesi olan 16 il, toplamda 30 büyükşehir araştırmanın evrenini, Denizli büyükşehir ve ilçe belediyeleri ise örneklemini oluşturmaktadır. Alan araştırmasında kullanılan anket ${ }^{11}$, büyükşehir belediye başkanı ve ilçe belediye başkanları olmak üzere 20 belediye başkanına yüz yüze uygulanmıştır. Çalışmada, 3'lü Likert tipi anket uygulaması yapılmıştır. $\mathrm{Bu}$ ankette 9 demografik, 45 araştırma konusuna yönelik olmak üzere 54 soru yer almıştır.

Verilerin değerlendirilmesinde veriler arasında kavramsal sonuçlara ve anlamlı bağlantılara ulaşmayı hedefleyen 'içerik analizi' yöntemi kullanılmış; elde edilen

${ }^{10}$ YSK verilerinden yazarlar tarafından derlenmiştir.

${ }^{11}$ Sayısal verilerle araştırma konuları arasındaki ilişkileri ortaya koyan nicel araştırmadan ziyade davranışları ve deneyimleri tanımlamak amacıyla kullanılan nitel araştırma yöntemi bu araştırma için tercih edilmiştir. Nicel araştırmalar daha büyük örneklem grupları gerektirirken nitel araştırmalar daha sınırlı örneklemi tercih edebilmektedir. 
bulgular; frekans, yüzde, birikimli yüzde, güvenirlik analizi tekniklerinden yararlanılarak SPSS Statistics 22 WİN programıyla çözümlenmiştir. Güvenilirlik test sonuçlarının $0,60 \leq \alpha<0,800$ ise ölçek oldukça güvenilir olduğundan, çalışmada yapılmış olan anket sonuçlarının oldukça güvenilir olduğu belirtilebilir.

\section{Tablo 6: Anket Sorularının Güvenilirlik Oranları}

\begin{tabular}{|c|c|}
\hline Cronbach's Alpha & N of Items \\
\hline 0,711 & 45 \\
\hline
\end{tabular}

Makalede belediyeler, büyükşehir ve ilçe belediyeleri, belediye yönetimindeki parti (siyasi farklılık), merkeze uzaklık, nüfus, mahalle sayısı, gelişmişlik, yüzölçümü ölçütleri de dikkate alınarak gruplandırılmışlardır.

\section{Tablo7: İlçe Belediyelerinin Farklılıklarına Göre Gruplandırılması}

\begin{tabular}{|c|c|c|}
\hline \multirow{3}{*}{$\begin{array}{c}\text { Belediye } \\
\text { Yönetimindeki } \\
\text { Parti }\end{array}$} & AKP & $\begin{array}{l}\text { Pamukkale, Merkezefendi, Acıpayam, Babadağ, Baklan, } \\
\text { Beyağaç, Çameli, Çardak, Çivril, Güney, Honaz, Kale, } \\
\text { Sarayköy, Serinhisar, Tavas }\end{array}$ \\
\hline & $\mathrm{CHP}$ & Bekilli, Bozkurt, Buldan \\
\hline & MHP & Çal \\
\hline \multirow{2}{*}{ Nüfus } & $\mathrm{Az}$ & $\begin{array}{l}\text { Babadağ, Baklan, Bekilli, Beyağaç, Bozkurt, Çameli, } \\
\text { Çardak, Güney, Serinhisar }\end{array}$ \\
\hline & Çok & $\begin{array}{l}\text { Pamukkale, Merkezefendi, Acıpayam, Buldan, Çal, Çivril, } \\
\text { Honaz, Kale, Sarayköy, Tavas }\end{array}$ \\
\hline \multirow[t]{2}{*}{ Yüzölçümü } & Dar & $\begin{array}{l}\text { Merkezefendi, Babadağ, Baklan, Bekilli, Beyağaç, } \\
\text { Bozkurt, Buldan, Çardak, Güney, Honaz, Sarayköy, } \\
\text { Serinhisar }\end{array}$ \\
\hline & Geniş & Pamukkale, Acıpayam, Çal, Çameli, Çivril, Kale, Tavas \\
\hline \multirow{2}{*}{ Mahalle Sayıs1 } & $\mathrm{Az}$ & $\begin{array}{l}\text { Babadă̆, Baklan, Bekilli, Beyağaç, Bozkurt, Çardak, } \\
\text { Güney, Honaz, Serinhisar }\end{array}$ \\
\hline & Çok & $\begin{array}{l}\text { Pamukkale, Merkezefendi, Acıpayam, Buldan, Çal, } \\
\text { Çameli, Çivril, Kale, Sarayköy, Tavas }\end{array}$ \\
\hline \multirow{2}{*}{$\begin{array}{l}\text { Merkeze } \\
\text { Uzaklık }\end{array}$} & Yakın & $\begin{array}{l}\text { Pamukkale, Merkezefendi, Babadağ, Bozkurt, Buldan, } \\
\text { Honaz, Sarayköy, Serinhisar, Tavas }\end{array}$ \\
\hline & Uzak & $\begin{array}{l}\text { Acıpayam, Baklan, Bekilli, Beyağaç, Çal, Çameli, Çardak, } \\
\text { Çivril, Güney, Kale }\end{array}$ \\
\hline \multirow{2}{*}{ Gelişmişlik } & $\mathrm{Az}$ & $\begin{array}{l}\text { Acıpayam, Baklan, Bekilli, Beyağaç, Çal, Çameli, Güney, } \\
\text { Kale, Tavas }\end{array}$ \\
\hline & Çok & $\begin{array}{l}\text { Pamukkale, Merkezefendi, Honaz, Sarayköy, Babadağ, } \\
\text { Çardak, Serinhisar, Bozkurt, Buldan, Çivril }\end{array}$ \\
\hline
\end{tabular}


Belediyelerin gruplandırılmasında en çok nüfusa sahip olan ilçe belediyesi durumundaki Çivril'in nüfusunun (60.716 kişi) yarısı az/çok gruplamasının orta değeri konumundadır. 30.358 nüfusun altındakiler az nüfuslu, üstündekiler çok nüfuslu ilçeler olarak değerlendirilmiştir. Gruplandırmalarda Denizli'nin toplam yüzölçümünün $\left(12.134 \mathrm{~km}^{2}\right)$ ilçe sayısına göre ortalaması $\left(638 \mathrm{~km}^{2}\right)$ gruplamanın orta değerini oluşturmaktadır. 638 km²'nin altında yüzölçümüne sahip olan ilçeler dar, üstünde olanlar geniş yüzölçümüne sahip ilçeler olarak değerlendirilmiştir. Gruplandırmalarda Denizli'nin toplam mahalle sayısının (623 adet) ilçe sayısına göre ortalaması (32 adet) gruplamanın orta değerini oluşturmaktadır. 32 ve daha fazla mahallesi olan ilçeler çok, daha az olan ilçeler ise az ilçeler olarak değerlendirilmiştir. Gruplandırmalarda Denizli merkeze en uzak olan ilçenin (106 $\mathrm{km})$ yarısı $(53 \mathrm{~km})$ uzak/yakın gruplamasının orta değerini oluşturmaktadır. 53 km'den daha uzak olanlar uzak ilçeler, daha yakın olanlar yakın ilçeler olarak değerlendirilmiştir. Gruplandırmalarda kamu hizmetleri ve ekonomik açıdan yapılan değerlendirmelerde gelişmişlik listesinin ilk 10 ilçesi çok gelişmiş, diğer 9 ilçe ise az gelişmiş ilçe olarak değerlendirilmiştir.

\section{Bulgular ve Tartışma}

Demografik sorular haricinde ankete katılan belediye başkanlarına 6360 sonrası dönemde hizmet sunumuna ilişkin değerlendirmelerini ortaya koymaya yönelik olarak 45 ifadeye katılım durumları sorulmuştur. Bu gruptaki ifadelerle belediye başkanlarının kanunun olumlu buldukları, eleştirdikleri taraflarının, kanunun uygulanmasındaki sorunlara ve çözüm önerilerine ilişkin değerlendirmelerinin ortaya konulması amaçlanmıştır.

Çalışmada belediyeler yönetimdeki parti, büyükşehir veya ilçe belediyesi olması yanında merkeze uzaklık, nüfus, mahalle sayısı, gelişmişlik, yüzölçümü açısından da gruplandırılmış ve bu farklılıkların cevaplara nasıl yansıdığı analiz edilmiştir.

Tablo 7'den de takip edileceği üzere, nüfus ve mahalle sayısı açısından yapılan gruplandırmada aynı belediyeler yer almaktadır. Bunun istisnası Çameli ilçesidir. Nüfusu az ancak mahalle sayısı çoktur. Diğer yandan merkeze yakın ilçeler ile gelişmiş ilçe belediyelerinin de aynı belediyeler olduğu görülmektedir. İstisnaları Tavas ve Çardak’tır; Tavas merkeze görece yakın ancak daha az gelişmiş, Çardak ise merkeze uzak ancak gelişmiş belediyeler sınıfındadır.

Denizli büyükşehir ve ilçe belediye başkanlarının 6360 sayılı kanuna ilişkin değerlendirmelerinin ölçüldüğü anketten elde edilen sonuçlar göstermektedir ki, siyasi parti farklılığı, ilçe belediye başkanlarının verdikleri cevapları farklılaştıran en kuvvetli kriterdir. İktidar partili ilçe belediye başkanları genellikle 6360 düzenlemesini ve uygulamalarını olumlu bulurken muhalefet partili ilçe belediyeleri de genellikle olumsuz bulmuş ve sorunları onaylar cevaplar vermişlerdir. Büyükşehir belediyesi de benzer biçimde genellikle kanun ve uygulamalarına olumlu yaklaşmaktadır. 
6360 sayılı kanunla ilgili olarak belediye başkanlarının kuvvetli biçimde olumlu bulduğu/yüksek oranda katıldığı düzenlemeler şunlardır:

- "Büyükşsehir statüsüne geçilmesi altyapı planlamasında bütünlüğü sağlamaktadır" (\% 80) ifadesine mahalle sayısı ve nüfusu çok olan belediyelerin yaklaşık \%70’i katılıyorum cevabı vermiştir. Yerleşim yerlerinin altyapı çalışmaları için ayıracağı bütçelerinin az olması ya da olmamas1 beraberinde personel yetersizliklerinin de olmas1 altyap1 çalışmalarını durma noktasına getirmiştir. Denizli'de içme ve kullanma suyu tesisi olmayan yer yoktur ancak kanalizasyon sistemi olmayan yerleşim yerleri vardır. Yolu olmayan yerleşim yeri olmasa da bakıma ihtiyacı olan yol sayısı oldukça fazladır. $\mathrm{Bu}$ gibi altyapı sorunlarını gidermek için il genelinde ciddi bir çalışma, zaman ve ödenek ihtiyacı vardır. Özellikle çevre ve toplum sağlığı açısından azami öneme sahip olan atık bertaraf çalışmaları ve temiz su kullanımının tek bir merkezden sağlanması uzak mahallelerde yaşayan vatandaşlar için çok büyük bir öneme sahiptir.

- "Büyükşehir belediyesi sınırlarının il sınırlarına kadar genişlemiş olması vatandaşa daha etkin hizmet sunulması açısından olumlu bir gelişmedir" (\% 70) ifadesine katılım oranları, nüfusu ve mahallesi çok olan belediyelerde daha fazladir.

- "Büyükşehir belediyesi (il) sınırlarındaki köylerin/beldelerin mahalleye dönüştürülmesi uygundur" (\% 70) ifadesine katıldıklarını belirtenler içinde nüfusu ve mahallesi çok olan belediyeler daha fazladır.

- "Il özel idarelerinin kapatılması uygundur" (\% 60) ifadesinde katılmayanlar nüfusu ve mahallesi çok olan belediyelerdir. Merkeze yakın ve gelişmiş ilçelerin çoğunlukla "katılıyorum" cevabı verdikleri görülmektedir. Çok yakınlarında gördükleri ve bildikleri hizmetleri bürokratik engeller nedeniyle alamamış olmaları bu belediye başkanlarının il özel idarelerinin kapatılmasını olumlu bulmalarındaki en önemli sebebi olarak düşünülebilir.

- "Büyükşehir statüsüne geçilmesi imar ve planlama bütünlüğü sağlamaktadır" (\% 70) fikrinde olanların mahalle sayısı ve nüfusu çok olan belediyeler olduğu görülmektedir. Birbirlerinden bir cadde ile ayrılan belde belediyelerinin almış olduğu farklı kararlar iki komşu için farklı uygulamalar anlamına gelmekteydi. 6360 sayılı kanunla bir bütünlük sağlanmış, tüm uygulamalar için karar mercii tek olmuş, farklı uygulamaların bu şekilde önüne geçilmiştir (Genç, 2014, s. 21-22).

- "Büyükşehir düzenlemesiyle ilçe belediyeleri arasında koordinasyon sorunları artmıştır" (\% 60) ifadesine nüfusu çok olan ilçelerin katılma oran1 \%54,5; yüzölçümü dar ilçelerin \%46,6; gelişmiş ilçelerin \%42,1; merkeze yakın ilçelerin \%50; büyükşehir belediyesinin \%50'dir. Bu 
sonuçlar ilçe belediyeleri arasında koordinasyonun henüz sağlanamadığını göstermektedir.

- “İlçelerde büyükşehir belediyelerinin yerel hizmet ofisleri açılmalıdır" (\% 70) ifadesine büyükşehir belediyesi \%100 katılmaktadır. Yerel hizmet ofislerinin açılması hususunda büyük bir beklenti vardır. Nüfusu ve mahalle sayısı fazla olan belediyeler de bu ifadeye katılmaktadır. İlçelerdeki faaliyetler hakkında bilgi vermek, sunulan hizmetlerin değerlendirilmesi, memnuniyet oranının tespiti, yapılan değişikliklerin ve yapılacak olanların duyurulması, iletişim engelinin aşılması gibi amaçlarla yerel hizmet ofisleri açılmalıdır.

- "Genel bütçe vergi gelirlerinden ilçe belediyelerine ve büyükşehir belediyesine ayrılan paylar yeniden düzenlenmelidir" (\% 85) ifadesine büyükşehir belediyesi, nüfusu ve mahallesi fazla olan belediyeler daha yüksek oranda katılmaktadır.

Belediye başkanlarının olumlu bulduğu düzenlemeler aşağıda sıralanmaktadır. $\mathrm{Bu}$ grupta iktidar partili belediyeler ile nüfusu ve mahalle sayısı fazla olan belediyelerin ifadelere katılma oranı yüksektir.

- Büyükşsehir statüsü yönetici-vatandaş ilişkilerini güçlendirmiştir. (\% 55)

- Büyükşehir yönetimine geçilmesiyle ilçe belediyelerinin büyükşehir belediyesine bağımlılı̆̆ artmıştır. (\% 55)

- Büyükşehir düzenlemesine geçtikten sonra ilçe halkının yerel kamu hizmetlerine ulaşımı kolaylaşmıştır. (\% 55)

- Büyükşehir belediyesi (il) sınırlarındaki mahalli idare birliklerinin kapatılması olumludur (\% 53)

- Büyükşehir düzenlemesiyle yeni ilçelerin kurulması olumlu olmuştur. (\% 50)

- Büyükşehir düzenlemesine geçtikten sonra ilçede sunulan yerel hizmetlerin verimliliği artmıştır. (\% 50)

- Büyükşehir statüsüne geçilmesinin ardından su faturalarından şikâyetler artmıştır. (\% 50)

- Belediyemizin mali özerkliği azalmıştır. (\% 50)

- Büyükşehir düzenlemesi merkeziyetçiliği artırmıştır. (\% 50)

Belediye başkanlarının olumlu bulduğu ancak katılma oranının \%50'nin altında olduğu, katılmama ve kısmen katılma seçeneklerinin de yüksek olduğu; dolayısıyla memnuniyet düzeyinin çok fazla olmadığı, neredeyse katılmamaya yakın tercihlerin yapıldığını düşünebileceğimiz; düşük katılım oranıyla olumlu gördüğ̈̈i/katıldığı ifadeler, uygulamalar aşağıda belirtilmektedir. Bu grupta iktidar partili belediyeler ile nüfusu ve mahalle sayısı fazla, merkeze yakın, gelişmiş ve yüzölçümü geniş belediyelerin katılım oranı daha fazladır. 
- Yatırım İzleme Koordinasyon Başkanlığının çalışmalarını olumludur. ( \% 45)

- Büyükşehir statüsüne geçilmesi ulaşım planlamasında bütünlügü sağlamıştır. (\% 43)

- Köyden dönüşen mahallelerde ulaşımla alakalı sorunlar yaşanmaktadır. (\% 40)

- Büyükşehir düzenlemesi yerelleşmeyi artırmıştır. ( \% 48)

- Büyükşehir yönetimine geçilmesiyle ilçe belediyelerinin temsil imkanı azalmıştır. (Katılma oranı \% 35, kısmen katılanların oranı \% 40)

- "Büyükşehir belediyesi ile imar yetkilerinin bölüşümünde ve uygulanmasında sorunlar yaşanmaktadır" ifadesine nüfusu ve mahalle sayısı çok olan belediyeler katılmamakla beraber, yüksek oranda "kısmen katılıyorum" şeklinde cevap verenler de bulunmaktadır (Katılma oranı \% 35 , k1smen katılanların oranı \% 35)

Belediye başkanlarının kuvvetli biçimde katılmadığı düzenlemeler aşağıda sıralanmaktadır. Bu grupta iktidar partili belediyeler ile nüfusu ve mahalle sayısı fazla, merkeze yakın, gelişmiş ve yüzölçümü geniş belediyelerin söz konusu ifadelere katılmama oranı yüksektir.

- Köylerin mahalleye dönüştürülmesi hizmet etkinliğini azaltmıştır. (\% 70)

- Köylerin mahalleye dönüştürülmesi tarım ve hayvancılık faaliyetlerini olumsuz etkilemiştir. (\% 65)

- Büyükşehir ve ilçe belediyeleri arasındaki siyasi çekişmeler ilçe belediyelerinde hizmet sunumunu olumsuz etkilemektedir. (\% 60)

- Büyükşehir belediye modeli öncesine geri dönülmelidir. (\% 60)

- Mahalli idare birlikleri yeniden kurulmalıdır. (\% 60)

- Belde belediyelerine tüzel kişiliği geri verilmelidir. (\% 65)

- Köylere tüzel kişiliği geri verilmelidir. (\% 70)

Belediye başkanlarının katılmadığı görüşler aşağıda sıralanmaktadır. Bu grupta iktidar partili belediyeler ile nüfusu ve mahalle sayısı fazla, merkeze yakın, gelişmiş ve yüzölçümü geniş belediyelerin katılım oranı düşüktür.

- Büyükşehir düzenlemesi sonrasında halkın altyapı konusundaki şikayetleri artmıştır. (\% 50)

- Büyükşehir düzenlemesi sonrasında ilçemizde ulaşım şikâyetleri artmıştır. (\% 50)

- Büyükşehir düzenlemesiyle büyükşehir belediyesi ile aramızda koordinasyon sorunları yaşanmaktadır. (\% 55)

- Büyükşehir düzenlemesi yerel demokrasi açısından uygun değildir. (\% 55) 
- Özellikle eski orman köylerine/yeni mahallelere hizmet götürmede sorunlar yaşamaktayız. (\% 55)

- Eski köylere/yeni mahallelere hizmet götürme konusunda personel açısından sorunlar yaşamaktayız. (\% 50)

- Eski köyler/yeni mahallelerin ilçe merkezine uzak olması hizmet sunumunu olumsuz etkilemektedir. (\% 50)

- Eksi köyler/yeni mahallelerin ilçe merkezi ile arasında coğrafi engeller hizmet sunumunu olumsuz etkilemektedir. (\% 50)

- Tüzel kişiliği kaldırılan belde ve köylerde yaşayanlarda aidiyet sorunu yaşanmaktadır. (\% 50)

Belediye başkanlarının katılmama oranının \%50 den düşük, kısmen katıliyorum cevabı verenlerin oranı yüksek; dolayısıyla katılmayanlar kadar bu konularda katılımcıların önemli bölümünün de kısmen memnuniyetsizlik duyduğu ve katıldığını düşünebileceğimiz konular aşağıda sıralanmaktadır. Bu grupta da iktidar partili belediyeler ile nüfusu ve mahalle sayısı fazla, merkeze yakın, gelişmiş ve yüzölçümü geniş belediyelerin katılmama oranı düşüktür.

- Büyükşehir statüsüne geçilmesi yazışmaları/bürokrasiyi artırmıştır. (Katılmama oran1 \% 30, kismen katılanlar \% 40)

- Belediyemizin sorumluluk sahasının genişlemesi hizmet sunumunda aksamalara neden olmaktadır. (Katılmama oranı \% 40, kısmen katılanlar $\%$ 30)

- Büyükşehir statüsüne geçilmesi hizmet maliyetlerini azaltmıştır. (Katılmama oran1 \% 35, kısmen katılanlar \% 45)

- Yeni mahallelere hizmet götürme konusunda teknik ekipman, araç-gereç sorunu yaşamaktayız. (Katılmama oranı \% 40, kısmen katılanlar \% 20)

- Büyükşehir belediyesi düzenlemesiyle belediyelerle mülki idarelerle arasında görev ve yetki çatışmaları yaşanmaktadır. (Katılmama oranı \% 40, kısmen katılanlar \% 35)

- Büyükşehir düzenlemesi sonrasında ilçemizde imar düzenlemeleri konusundaki şikâyetler artmıştır. (Katılmama oranı \% 45, kısmen katılanlar \% 20)

\section{Sonuç}

Denizli büyükşehir ve ilçe belediyeleri özelinde yapılan bu çalışmadan elde edilen sonuçlar 6360 sayılı kanunun gerekçesinde belirtilen, beklenen faydaların ortaya çıkması konusunda kanun yapıcı ile büyük ölçüde benzer sonuçlara ulaşmışır. Literatürde 6360 sayılı kanun konusunda yazılan lehte ve aleyhte görüşler itibariyle (Genç, 2016a, s. 283) anketlerden elde edilen sonuçlar değerlendirildiğinde, imar bütünlüğünü sağlama konusundaki olumlu görüşlerin anketlerle de desteklendiği buna karşılık yine literatürde dile getirilen büyükşehir ve ilçe belediyeleri arasında görev ve yetki uyuşmazlıklarının yaşanması, ikili 
yap1, kırsal alana hizmet götürmede güçlükler yaşanması, demokratik katılım ve temsil konularında sorunlar yaşanacağı yönündeki eleştirilerin anketlerden elde edilen sonuçlarla desteklenmediği görülmektedir.

Literatürden, alan araştırmasına dayanan önceki çalışmaların sonuçları ile Denizli özelinde yapılan bu çalışmayı karşılaştırmak da mümkündür. Bu çalışmada, belediye yöneticileri belediye hizmet alanlarının il ve ilçe mülki sınırlarına kadar genişlemesiyle vatandaşlara daha etkin hizmet verilebileceği değerlendirilmektedir. Genç ve Daşçı'nın (2016) Balıkesir üzerine yaptıkları çalışmada da benzer ifadeye "katılıyorum" oranı \%65'tir. Okçu vd.nin (2016, s. 150) yaptığı çalışmada da "30 Mart yerel seçimleri sonrası büyükşehir belediyesi sınırlarının il sınırlarına kadar genişlemiş olması vatandaşa daha etkin hizmet sunulması açısından olumlu bir gelişmedir" ifadesine genel olarak "katılıyorum" cevabının alındığı görülmüştür. Anket uygulanan illerde olumlu cevapların oranları şöyledir: Antalya \%56,9 Ankara \%56,6, Diyarbakır \%80,7; Kocaeli \%69, Samsun \%74,8, İzmir \%38, Erzurum ise \%73,6. Yeni düzenleme konusunda en olumlu değerlendirmeye Diyarbakır'ın sahip olduğu, en olumsuz kanaate de İzmir'in sahip olduğu görülmüştür. Belde ve köylerin mahalleye dönüşmesi, olumlu karşılanmaktadır. Arıkboğa vd. (2007, s. 109-110) İstanbul Büyükşehir Belediyesinin 98 meclis üyesi üzerine yaptıkları çalışmada ilk kademe (belde) belediyelerin büyükşehir belediye sistemi içine alınmasını inceledikleri çalışmalarında katılımcıların \%33'ü kesinlikle doğru, \%47'si ise doğru bulduğunu belirtmiştir.

Anket sonuçlarına göre, büyükşehir statüsüne geçilmesinin imar ve planlama bütünlüğü sağladığı düşünülmektedir. Okçu vd. (2016, s. 153) araştırmasında da "Büyükşehir belediyesinin imar yetkisi kent bütünlügü açısından doğrudur" ifadesine genel olarak katılımcıların "katılıyorum" cevabını verdikleri görülmüştür. Söz konusu çalışmada katılımcıların il ölçeğinin doğru olduğu düşüncesini paylaşanların; Antalya (\%59,7), Ankara (\%51,3), Diyarbakır (\%65,7), Kocaeli $(\% 53,3)$, Samsun $(\% 71,2)$ ve Erzurum $(\% 71,1)$ olduğu; bu yöntemi en az doğru bulan illerin ise İzmir $(\% 39,8)$, Antalya $(\% 29,1)$ ve Ankara $(\% 29,8)$ olduğu görülmüştür. $\mathrm{Bu}$ anlamda literatürdeki benzer görüşü destekleyen sonuçlara ulaş1lmıştır (Genç, 2014, s. 6, 21-22; Savaş Yavuzçehre, 2005, s. 84).

Anket sonuçlarına göre, belediye başkanlarının büyükşehir statüsüne geçilmesinin hizmet maliyetlerini azalttığı fikrine katılmadıkları sonucu çıkmaktadır. Özellikle küçük ve geliri az ilçe belediyeleri için kent merkezinde uzak, kırsal arazi şartlarının yarattığı güçlükler ulaşım maliyetlerini artırdığı gibi zaman ve işgücü kaybına da sebep olabilmektedir. Bu maliyetlerin düşmesi için büyükşehir belediyelerinin ilçelerde yerel hizmet birimlerini kurmaları ankete katılan yerel yöneticiler tarafından çözüm olarak görülmektedir.

Yatırım İzleme Koordinasyon Başkanlığının (YİKOB) çalışmalarının olumlu olduğu fikrine belediye başkanlarının büyük bölümü katılmamaktadır. Bu 
sonuçlardan henüz YİKOB'un fonksiyonunun tam olarak anlaşılamadığı veya hissedilemediği sonucunu çıkarmak da mümkündür.

Büyükşehir statüsüne geçilmesinin yazışmaları/bürokrasiyi artırdığı görüşüne katılmayanlar kadar katılanların oranı da yüksektir. Genç ve Daşçı'nın (2016) Balıkesir üzerine yaptıkları çalışmada ise bürokrasinin arttığ 1 fikrine yerel yöneticilerin katılmadığı görülmektedir. Büyükşehir belediyesi-ilçe belediyeleri, ilçe belediyesi-ilçe belediyesi arasında koordinasyonun sağlanması, hizmet bütünlüğünün sağlanması açısından yazışmalar artmaktadır. En üst düzeyde hizmet sunumunun sağlanması, koordinasyon eksikliklerinin giderilmesi zamanla bu yükü azaltabilecektir.

Büyükşehir yönetimine geçilmesiyle ilçe belediyelerinin büyükşehir belediyesine bağımlılığının arttığı görüşünü paylaşan belediye başkanlarının sayısı fazladır. 6360 sayılı kanunla ilçe belediyelerinin büyükşehir belediyesine bağımlılığı artmış; önceki durumlarıyla kıyaslandığında bağımlılık ve vesayet ilişkileri artmıştır.

Eski köyler/yeni mahallelerin ilçe merkezi ile arasında coğrafi engellerin hizmet sunumunu olumsuz etkilediği görüşüne katılanların sayısı yüksektir. Benzer şekilde Genç ve Daşçı'nın (2016) Balıkesir üzerine yaptıkları çalışmada yerel yöneticilerin coğrafi engellerden kaynaklanan sorunlar yaşadıklarını beyan ettikleri görülmektedir.

Çalışmada söz konusu sorunlara dair ne tür çözüm önerileri olduğu konusunda da katılımcılara bazı ifadeler yöneltilmiştir. Bunlara ilişkin cevaplara bakıldığında, büyükşehir modelinin terk edilmemesi; büyükşehir belediyesinin ilçelerde yerel hizmet ofisleri açması gerektiği düşünülmektedir. Belediye başkanları genel bütçe vergi gelirlerinden ilçe belediyelerine ve büyükşehir belediyesine ayrılan payların yeniden düzenlenmesi gerektiği fikrine yoğun biçimde katılmaktadırlar. Buna karşılık mahalli idare birliklerinin yeniden kurulmasına, köylere ve belde belediyelerine tüzel kişiliklerinin geri verilmesine sıcak bakmamaktadırlar.

Bunun yanında, anket sonuçları katılanların çoğunlukta olduğu ancak katılmayan veya kısmen katıldığını beyan edenlerin de fazla olduğu konulara bakılarak değerlendirildiğinde büyükşehir ve ilçe belediyeleri arasındaki bürokratik düzenlemelerde iyileştirme; görev ve yetkilerin netleştirilmesi ihtiyacı olduğu; özellikle ilçe belediyelerinin hizmet alanının genişlemesi, uzaklık ve coğrafi engellerin bazı belediyeleri hizmet, teknik araç-gereç, personel, ulaşımla alakalı sorunlar yaşadıkları, bazı belediyelerin temsil olanaklarının ve hizmet maliyetlerinin arttığını düşündükleri; imar düzenlemeleri konusunda şikayetlerin olduğu, YİKOB'ların görev ve fonksiyonunun tam anlaşılamadığı da anlaşılmaktadır. Dolayısıyla bu başlık altındaki konularda kanun ve uygulamasında iyileştirici birtakım düzenlemelerin yapılmasına ihtiyaç olduğu söylenebilir. 


\section{Kaynakça}

Adıgüzel, Ş. (2014). Hatay büyükşehir belediyesi, ADÜ SBE Dergisi, Büyükşsehirler Özel Sayısı, Özel sayı, 30-53.

Arıkboğa, E., Oktay T., Yılmaz N. (2007). Yeniden yapılanma sonrasında belediye meclisleri: Istanbul örneği. İstanbul: Beta Yayınları.

Arıkboğa, E. (2008). 5393/11: Devam eden/edemeyen reform, 1. Yerel Yönetimler Seтровуити (17-34). İstanbul: Erkam Matbabas1.

Çınar T, Ciner C.U., Zengin, O. (2009). Büyükşehir yönetimi bütünleştirme süreci, Ankara: TODAİE YYAEM.

Demirkaya Y., Koç M. (2017). 6360 Sayılı kanun ile birlikte mahalleye dönüşen köylerde değişimin katılım açısından muhtarlığa etkisi: menteşe ve seydikemer ilçeleri üzerinden bir değerlendirme. Strategic Public Management Journal, 3(6), 124-149.

Denizli Büyükşehir Belediyesi (2018). İlçe Belediyelerimiz, http://www.denizli.bel.tr/Default.aspx?k=content\&id=14225 (Erişim Tarihi 7.11.2018)

Denizli Valiliği (2018) Tarihçe, http://www.denizli.gov.tr/tarihce (Erişim 7.11.2018).

Genç F. N., Özgür H. (2009). Orta ölçekli kentsel alanların yönetimi: aydın merkez ilçe ve kuşadası-söke örnekleri. TODAIE-4. Yerel Yönetimler Sетровуити (289-300). Ankara: Desen Ofset.

Genç F. N. (2014). 6360 sayılı kanun ve aydın'a etkileri. Adnan Menderes Üniversitesi Sosyal Bilimler Enstitüsü Dergisi, Özel Sayı, 1-29.

Genç F. N. (2014). Gecekonduyla mücadeleden kentsel dönüşüme Türkiye'de kentleşme politikaları. Adnan Menderes Üniversitesi Sosyal Bilimler Enstitüsü Dergisi, 1 (1), 15-30.

Genç, F.N. (2016a). 6360 Sayılı yasa ve büyükşehir belediyelerinde dönüşüm. Y. Demirkaya (Ed.). Türkiye'de Yeni Kamu Yönetimi: Yerel Yönetim Reformu içinde (s. 271-299). İstanbul: WALD Yayınları.

Genç, F. N (2016b). Türkiye'de büyükşehir belediye sisteminde 6360 sayılı kanun ve etkileri. U. Ömürgönülşen, U. Sadioğlu (Ed.). 6360 Sayılı Yasanın Getirdiği Yeni Büyükşsehir Modeli ve Uygulama Sonuçları içinde (s.188195). Ankara: Hacettepe Üniversitesi Yerel Yönetimler Uygulama ve Araştırma Merkezi Yayını, Hacettepe Üniversitesi Basımevi.

Genç, F. N ve Daşçı S. (2016). 6360 sayılı kanunun kamu hizmetlerinin sunumuna etkisi: balıkesir büyükşehir belediyesi örneği. Journal Of Socıal And Humanitıes Sclences Research 6 (2), 30-61. 
Genç F. N., Korkın E. (2017). 6360 Sayılı kanunla tüzel kişiliği kaldırılan belde belediyelerinde halkın uygulamaya ilişkin algısı: atça (sultanhisar-aydın) örneği. KMÜ Sosyal ve Ekonomik Araştırmalar Dergisi 19 (32), 84-95.

Göküş, M., Alptürker H. (2016). 6360 sayılı yasa ile köy yönetiminden mahalle yönetimine geçiş sonrası etkin hizmet sunumuna ilişkinmuhtarların görüşü: silifke köyleri örneği. Selçuk Üniversitesi Sosyal ve Teknik Araştırmalar Dergisi, 11, 67-86.

İzci, F. ve Turan, M. (2013). Türkiye'de Büyükşehir Belediyesi Sistemi Ve 6360 Sayılı Yasa İle Büyükşehir Belediyesi Sisteminde Meydana Gelen Değişimler: Van Örneği. Süleyman Demirel Üniversitesi İktisadi ve İdari Bilimler Fakültesi Dergisi, 18 (1), 117-152.

Karaarslan M. (2012). Nas1l bir yerel yönetim. Dicle Üniversitesi Hukuk Fakültesi Dergisi, 17-18, (26-27-28-29), 123-162.

Kılınç Ürkmez, G. ve Zengin Çelik, H. (2016). 6360 Sayılı yasayla mekânsal ilişki sisteminin kır- kent ikileminde yeniden yapılanışı ve yerel yönetimler: Kayseri İli örneği. Çağdaş Yerel Yönetimler, 25 (3), 69-94.

Okçu Murat vd. (2016). 112 K 538 Nolu Yerel nitelikli hizmet sunumunda yeni ölçek arayışları: büyükşshir belediyeleri ve mahalli idare birlikleri üzerinden bir inceleme Adlı TÜBİTAK Projesi.

Özgür, H. (2005). Türkiye'de orta ölçekli kentsel alanların yönetimi sorunu. H. Özgür, M. Kösecik (Ed.). Yerel Yönetimler Üzerine Güncel Yazılar -1: Reform içinde (s. 471-498). Ankara: Nobel Yayın Dağıtım.

Özgür, H. (2007). Orta ölçekli kentsel alanların yönetimine ilişkin alternatifler,.H. Özgür, M. Kösecik (Ed.). Yerel Yönetimler Üzerine Güncel Yazllar -II: Uygulama içinde (s. 100-142). Ankara: Nobel Yayın Dağıtım.

Özgür, H. (2008). Belediye sayısının azaltılmasının tarihsel sürecine dair bir deneme. Yerel Siyaset Dergisi, 43-50.

Özgür, H. (2014). Denizli kenti ve ilinde yönetsel ölçek arayışları (1976-2004): dört bütünşehir belediyesi söylemi/tasavvuru (2001-2014) ve büyükşehir belediyesi statüsü (2012-2014). Adnan Menderes Üniversitesi, Sosyal Bilimler Enstitüsü Dergisi, 1 (5), 30-53.

Özgür, H., Savaş Yavuzçehre, P., Ciğeroğlu, M., (2007). Türkiye'de orta ölçekli ve metropoliten kentsel alanların yönetimi. B. Eryılmaz B., Eken M., Şen M.L. (Ed.). Kamu Yönetimi Yazıları içinde (s. 475-514). Ankara: Nobel Yayın Dağıtım.

Özgür H. ve P. Savaş Yavuzçehre. (2016). Türkiye'nin büyükşehir belediyesi sistemi: 1982-2015. Çankır Karatekin Üniversitesi Sosyal Bilimler Enstitüsü Dergisi, 7(1), 903-926. 
Resmi

Gazete

(26.11.2016)

http://www.resmigazete.gov.tr/eskiler/2005/03/20050304-1.htm. (Erişim tarihi: 6. 11. 2018)

Savaş Yavuzçehre, P. (2005). Belediyelerin kentsel yaşam kalitesine etkileri denizli karşıyaka mahallesi örneği, Pamukkale Üniversitesi, Sosyal Bilimler Enstitüsü, Yüksek Lisans Tezi, Denizli.

Savaş Yavuzçehre, P. (2010). Kentsel mekân kullanımında değişim: denizli kenti örneği, Süleyman Demirel Üniversitesi, Sosyal Bilimler Enstitüsü, Doktora Tezi, Isparta.

TC BKKGM (2012) 6360 sayılı Kanunun Gerekçesi http://www2.tbmm.gov.tr/d24/1/1-0690.pdf (Erişim tarihi: 6. 11. 2018)

TEPAV (2014). - http://www.tepav.org.tr/upload/files/haber/13542876822.6360_Sayili_Yasaya_Gore_Belediyelerin_Genel_Butce_Vergi_Gelirleri nden_Alacaklari_Paylar.pdf. (Erişim tarihi: 6. 11. 2018)

Zengin, O. (2014). Büyükşehir sisteminin dönüşümü: son on y1lın değerlendirilmesi. Ankara Barosu Dergisi, 91-116. 


\section{Impact of Law No: 6360 of Public Service Provision: The Case of Metropolitan Municipality Denizli}

Extended Abstract

\section{Introduction}

With the Law No.6360 on the Establishment of the Fourteen metropolitan Municipalities and Twenty-seven Districts and the Amendment of Certain Laws and decree on the Decree Law, significant changes were made in the public administration system. In the study, comparative evaluations were made about the forms of administrative organization before and after the Law 6360. In the study, the effects on the public service of Denizli province of the Law No.6360 were evaluated. Further 20 mayors a questionnaire consisting of 54 questions, 9 demographic and 45 research questions were conducted to determine the effects of the Law 6360 on public service provision.

\section{Method}

The aim of this study is to evaluate the effects of the new regulations introduced by the Law No. 6360 on the service provision in Denizli and to investigate whether the benefits outlined in the justification of the law have emerged.

The study is based on literature review and field research. With the Law No. 6360, a total of 30 metropolitan municipalities, including 14 provinces that have been turned into metropolitan municipality and 16 provinces that had been changed as metropolitan municipality before constitute the population of research and Denizli metropolitan and district municipalities constitute the sample. The questionnaire used in the field research was applied to 20 mayors face to face, including the mayor and district mayors. In this study, 3-point Likert-type questionnaire was applied. In this survey, there were 54 questions consisting of 9 demographics and 45 research topics.

In the evaluation of the data, the "content analysis" method was used. The findings were grouped through the techniques of frequency, percentage, cumulative percentage reliability analysis in SPSS Statistics 22 WIN program.

In the article, municipalities, metropolitan and district municipalities, political party involving municipal administration (political difference) are grouped taking criteria of distance from the center, population, number of neighborhoods, development and area into question.

\section{Results and Discussion}

Regarding the Law No. 6360, regulations that the mayors strongly favored/strongly agreed are as the following: the transition to metropolitan status provides integrity in infrastructure planning; the expansion of the borders of the metropolitan municipality to the provincial borders is a positive development in terms of providing more efficient service to the citizens; turning villages/countries into neighborhoods is appropriate; closure of special provincial administrations is appropriate; the transition to metropolitan status provides the zoning and planning integrity; coordination problems between metropolitan municipalities and district municipalities have grown; local service offices of metropolitan municipalities should be opened in districts; the shares allocated to districts municipalities and the metropolitan municipality from the general budget tax revenues should be rearranged.

With the arrangements that the mayors found favorable, the municipalities of the ruling party and the municipalities with more population and districts were more likely to agree with the statements. These statements are as follows: metropolitan status has strengthened the relationship between the administrator and the citizen; after the metropolitan municipality regulation, the local people's access to local public services has been facilitated; the closure of the local administration 
units at the borders of the metropolitan municipality (province) is positive: the establishment of new districts with the metropolitan arrangement has been positive; the efficiency of the local services provided has increased following this regulation; complaints regarding bills increased after the transition to metropolitan status; the financial autonomy of our municipality has decreased; metropolitan regulation increased centralization.

It was found that the mayors were positive but the agreement rate was below 50\%; therefore, we can think that the level of agreement is not very high; almost negative. The statements and practices of the mayors with low participation rate are stated below. In this group, the agreement rate of the municipalities of the ruling party, whose population and the number of the neighborhoods are high, close to the center, and have large area, were high. These statements are as follows: The work of the Investment Monitoring Coordination Department is positive; the transition to metropolitan status has ensured integrity in transportation planning; there are problems with transportation in the neighborhoods that are transformed from villages; metropolitan regulation increased localization; the possibility of representation of the district municipalities decreased with the transition to the metropolitan administration: there are problems in the division and implementation of the zoning authority of the metropolitan municipality. While the municipalities with high population and ore neighborhoods do not agree with the statements, there are also "I partly agree" responses.

In the arrangements where the mayors disagree strongly, the disagreement rate of the municipalities of the ruling party whose population and the number of the neighborhoods are high, close to the center, developed and have large area was high. These statements are as follows; the transformation of villages into the neighborhood has reduced the effectiveness of the service; the transformation of villages into the neighborhood adversely affected agriculture and livestock activities; political conflicts between metropolitan and district municipalities have a negative impact on service provision in district municipalities; the status should be reinstated as before the metropolitan municipality model; local administrations should be re-established: the municipalities of the counties should be reinstated; legal personality should be reinstated to the villages.

Regarding the statements that the mayors did not agree, the disagreement rate of the municipalities of the ruling party that have high population and more neighborhoods, close to the center, developed and large-scale is low. These statements are as follows: after the metropolitan regulation, public complaints about the infrastructure have increased; following the metropolitan regulation, transportation complaints increased in our district; there is a problem between us and the metropolitan municipality regarding coordination; metropolitan regulation is not suitable for local democracy; in particular, we have problems in delivering services to old forest villages / new neighborhoods; we have problems with staff in providing services to old villages / new neighborhoods; as old villages / new neighborhoods are away from the district center, this adversely affects service provision; the geographic barriers between the district center and the old villages / new neighborhoods negatively affect service provision; the residents in the villages and counties whose status are amended, have a problem of belonging.

The disagreement rate of the mayors is less than $50 \%$, and the rate of those who partly agree is high; therefore, we can think that the level of disagreement is not very high; the disagreement rate of the municipalities of the ruling party, whose population and the number of the neighborhoods are high, close to the center, developed and have large area, was low. These statements are as follows; the transition to the metropolitan status increased the correspondence / bureaucracy; the expansion of our municipality's responsibility area leads to disruptions in service delivery; switching to metropolitan status reduces service costs; we are experiencing technical equipment problems in delivering services to new neighborhoods; following metropolitan municipality regulation, there are conflicts between civil administrations and municipalities regarding duty and authority; after the metropolitan regulation, complaints about zoning regulations have increased in our district. 


\section{Conclusion}

The results obtained from this study conducted in the case of Denizli metropolitan and district municipalities have reached similar results of the lawmaker in terms of the expected benefits outlined in Law No. 6360. In the literature, when the results obtained from the surveys are evaluated in terms of the favorable and unfavorable opinions written on the law no. 6360, it is seen that the criticism about conflicts between civil administrations and municipalities regarding duty and authority, difficulties in providing service to the rural area, problems in democratic participation and representation issues.

According to the results of the survey, it is concluded that the mayors did not agree that the transition to the metropolitan status decreased the service costs. In particular, the difficulties of remote rural district municipalities, especially of small and low income municipalities, increase transportation costs and cause time and labor loss. Local administrators regard establishment of local services in district by the metropolitan municipalities as a solution in order to decrease these costs. 